\title{
Strategic Role of Japanese Government in Promoting Halal Market in Japan
}

\author{
Muhammad Thamrin ${ }^{1}$, Asra Virgianita ${ }^{2}$ \\ $\left\{{ }^{1}\right.$ muhammadthamrin91yokatta@gmail.com, ${ }^{2}$ asrahiui@ui.ac.id $\}$ \\ ${ }^{1}$ School of Strategic and Global Studies, Universitas Indonesia, Indonesia \\ ${ }^{2}$ School of Strategic and Global Studies and Faculty of Social and Political Sciences, \\ Universitas Indonesia, Indonesia
}

\begin{abstract}
This study discusses the development of the halal market in Japan in terms of the Japanese government's strategy in optimizing its economy as one of the country's revenue solutions. The Japanese government is encouraged to support the halal market by promoting halal tourism and halal industry because of the interest of Muslim tourists from all over the world. Such as the provision of places of worship inside the airport, halal restaurant concept, and various other types of supporting facilities. Various policies that support the increasing tourist visit contributed to stimulate the halal market in the country. The role of government is considered very important in improving a country's economy seen from the theory of Thomas Oatley in regard to state-centered approach.
\end{abstract}

Keywords: halal market, economy, government

\section{INTRODUCTION}

The continent of Asia has the largest Moslem population compared to other continents. Halal (Lawful) products, such as food and beverages, medicines, and cosmetics must have been very commonly used and produced in Asia countries. Apart of the requirement for the Moslems, halal products utilized very well in terms of health due to their safe content from substances that harm the body, clean, and have good quality. Starting from here, finally not only Moslem countries, but also other countries, such as Thailand, South Korea, and Japan which tend to have fewer Moslem population commenced to get used to using halal products. These countries began opening many facilities and places that sell halal products (Kemendag, 2015)

The Organization of Islamic Cooperation (OIC) consisting of 57 Moslem-majority nations, is now commencing to discuss the potential and opportunities of halal products in the world market. In some of its conferences, the organization has discussed the value of the halalproducts sector in recent years and predictions that will increase the value in the upcoming year (Kemendag, 2015)

In Japan, halal food products lately are booming. Even the tourism agencies in various regions, ranging from Hokkaido to Okinawa, make a special description brochure for the Moslems. Similarly, Moslem tourists who come to Japan will increase more. The government of Japanis currently enforcing visa-free to some countries, one of which is a majority Moslem country such as Indonesia, Malaysia and so on (Sean, 2014) 
In its tourism policy, the government of Japan grants a special treatment to foreign tourists by conducting restaurant development that serves food menus that are not only healthy but also halal. This is as a new innovation from the government of Japanalong with other supporting infrastructures, aimed at providing comfort to foreign tourists (Sean, 2014: 5) The other supporting infrastructure covers the establishment of mushalla (praying room) reserved for Moslem visitors in a famous shopping center in Tokyo, namely Takashimaya, and such mushalla is equipped with ablution place and a pointer to the direction of Qiblah (Sean, 2014).

\section{PREVIOUS STUDIES}

In a $\mathrm{n}$ article written by Aditya Al Jamil (2015) entitled Motivasi Pemerintah Jepang Dalam Rencana Pemberian Bebas Visa Bagi Turis Asal Indonesia (Government of Japan Motivation in the Planning of Visa-Free Granting for Indonesian Tourists), explaining about the motivation of Japan policy to provide visa-free for Indonesian tourists. This study uses a descriptive method that benefits the explorative analytic research by trying to study the phenomena based on the existing data. Secondary data is obtained from the documentation media which includes data from the official website of the institution, books, magazines, newspapers, newsletters, internet, and other sources. The author uses the perspective of neoliberalism in which neo-liberalism assumes that the state is trying to maximize its absolute profits through cooperation. The national interest is the purpose of the implementation of foreign policy to a country. This study finds that Japan changed its policy orientation to tourist destination countries. The government of Japan considers that the tourism industry is a promising industry in the 21 stcentury. Initially, the government of Japan issued the visa-free policy for 67 countries including Indonesia. The motivation of Japan policy in granting the visa-free for Indonesia aims at targeting the increasing of foreign tourists to Japan before the 2020 Olympics in Tokyo. The implementation of Japan's visa-free policy towards Indonesia is a prerequisite for Indonesian citizens to have electronic passports, grant the multiple-entry visas to Indonesian citizens and extend the visit times from 15 to 30 days.

A study written by Septalia Anugrah Wibyaninggar (2016) which is discussing Japanese Tourism Strategy in the Context of Halal Tourism, explaining about the tourism that has an impact on the economy of a country. In Japan, tourism becomes a sector capable of having a positive impact on the economy. Japan's excellence that has wonderful natural scenery and unique culture becomes the allure for tourists from abroad. Tourists who visit to Japan have their own character. Moslem tourists whose the need for halal food must be the first concern. Coupled with the rise of Moslem tourists today who visit Japan the government of Japan has set up a certain strategy especially related to tourism by promoting the halal tourism.

\section{METHODOLOGY}

\subsection{Research Approach}

Based on the data type, the research approach used in this study is a qualitative approach. The qualitative research means that the research intended to understand the phenomenon of what the subject of research is experiencing holistically, and by way of descriptions in the form of words and language, in a specific context that is natural and by utilizing various scientific methods (Moleong, 2007). 
Meanwhile, the type of this research approach is the descriptive approach. Descriptive research is a research that seeks to tell the existing problem solving based on the data. The type of qualitative descriptive research used in this study is intended to obtain information on the development of halal market in Japan with its relation to the role of government in developing halal market. In addition, with a qualitative approach it is expected to disclose the situation and problems facing Japan in optimizing the halal market.

\section{DISCUSSION}

\subsection{Halal Market}

\subsubsection{Understanding the Halal Market}

Halal, or fully in Arabic is "halal thayyiban", has the halal and good meaning. In the case of food for example, halal food can be interpreted also as the food which is good for physical and spiritual health. The halal principalities of food and beverage products depend heavily on primary raw materials, additional raw materials and production processes. (Halal is not only limited to the substance, but also in the process of obtaining it). The concept of halal that comes from Islam, of course can be applied by the non-Moslems as well. Currently, the halal products rise in demand as the choice to live healthy and good life by the people from various countries in the world (Battour, 2010).

In the report from State of the Global Islamic Economy (2014-2015) issued by Thomson Reuters and Dinar Standard that the most promising opportunities in the economic sector for halal products, among them are as follows:

\subsubsection{Halal Foods and Beverages}

Foods and beverages which are forbidden to comply with the basic principles of the Holy Quran believed by Moslem as well as the Hadeeth or the words and life of the Prophet Muhammad, among others, the dead animals (carcasses), blood, pork, and the animals slaughtered / devoted to other than God, liquor. Currently, the focus of halal foods and beverages products are those that are good and pure (thayyib). The world's consumption level of Moslem population towards the halal food and beverage products in 2013 reached US \$ 1.29 billion with an increase of $10.8 \%$ over the previous year, and it is estimated that the value in 2019 will increase to US \$2.54 billion, equivalent to $21.2 \%$ of the world's total consumption.

- Moslem Tours

The tour which is "friendly" for Moslem tourists either from the aspect of facilities (the availability of places of worship, hotels with swimming pool for Moslem women, etc.) as well as the presence of halal food, Islamic travel packages (including Hajj and Umroh). This product / service consumption in 2013 reached US \$ 140 billion and is forecasted in 2019 to be US \$ 238 billion, equivalent to $11.6 \%$ of the world's total consumption.

- Modest Fashion

Clothing that puts forward the value of decency as stated in the Holy Quran and Hadeeth, which covers the body parts that are forbidden to be seen by others (aurat). In addition to such decency, the good (clean) and the quality of clothing also includes in terms of halal fashion. The world's consumption level of Moslem population towards this product in 2013 reached 
US \$ 266 billion and in 2019 is estimated to US \$ 488 billion (11.9\% of the world's total consumption).

- Media and Recreation

Media that has positive effect on the users and their family such as the digital content of social media, electronic media broadcasts, mass media, games, which have the Islamic themes and do not contradict with the principles in the Quran and Hadeeth. In 2013, this product had a value of US \$ 185 billion and the forecast of growth in 2019 will reach US \$ 301 billion, about $5.2 \%$ of the world'stotal consumption.

- Pharmaceutical and Cosmetics

Pharmaceutical products (vaccines, drugs, etc.) and cosmetics that contain non- unlawful materials prohibited by the Quran and Hadeeth (pigs, alcohols, etc.). In 2013, this product had a value of US \$ 72 billion and is estimated in 2019 to reach US \$ 103 billion or equivalent to $6.6 \%$ of the world'stotal consumption.

- Islamic Financial System

Financial system (retail / business finance, insurance, investment, etc.) aims ato operating the use of the basic principles in the Quran and Hadeeth which cover all business transactions and their impact, purpose and operation. This is related to the prohibition of usury in financial transactions. The Islamic financial system prohibits benefit thing the wealth or properties of others without any consent, and multiply the debt. The world's Moslem population of about 1.6 billion or $25 \%$ of the world's total population presents an opportunity for halal products business. Plus, this time the consumer of halal products is not only from the Moslem communities, but also from non-Moslem communities who want to start a healthy life. Thus, it can be predicted that the market size of halal products in the world is getting bigger and making the opportunity even higher. Some of the countries outside the Asian region that are interested in halal products, among others, United Arab Emirates (UAE) located in the Middle East, and Turkey, France, and Belgium located in the Europe.

The demand for halal products from these countries continues increasing. Currently, even the UK and the Netherlands have a halal area. It signifies the increasing number of halal product consumers in each country. The interest of producers in marketing the products for the Moslem market is due to the trade of halal products is not only growing rapidly in Europe but throughout the whole world. This makes Moslems as the fastest growing demographic group. Approximately 50\% of 2.7 million of Moslems is the young generation aged 30s. The young generation is increasingly aware nowadays of the importance of healthy life so that the halal and good (tayyib) foods and beverages become their choice.

\subsubsection{Global Halal Market Growth}

Global halal industry estimated to be worth about US \$ 2.3 trillion (excluding Islamic finance). The growth of this industry reaches $20 \%$ every year. The value of this industry is about US \$ 560 billion per year. This makes the halal food industry as one of the fastest growing sectors in the world. The global Moslem population is around $23 \%$ of the global population or about 1.8 billion consumers with an average growth rate of $3 \%$ per year. If this growth trend continues, Moslems are estimated at 26\%, projected at 2.2 billion by 2030 . Two major markets for halal products are Asia Pacific and the Middle East. More than half of the global Moslem population live in South Asia and Asia Pacific and the number of Moslems from such region is projected to reach 1.3 billion by 2030. Four out of ten countries in the world have the largest Moslem population lived in South Asia and Pacific regions: which are Indonesia, Pakistan, India and Bangladesh (Mori, 2015). 
The halal food sector it self is undoubtedly on the rise. The significant growth in recent decades is estimated to be worth of US \$ 667 million. With an increase both in the population and the income of halal consumers, thus, the demand for food will exceed $70 \%$ by 2050 , therefore, the future of halal food demand is looking stronger (Mori, 2015).

In addition, global trends show that not only the halal foods, but the halal foods certification services are increasing. There are also many global brands for seeking to obtainthe halal certification on their products in local markets, such as Barry Callebaut, Givaudan, McDonalds, Kentucky Fried Chicken (KFC), Monin and Nestle S.A. One example in this regard is the halal certification agency in Singapore, namely Majlis Ugama Islam Singapura (MUIS). Singapore's halal certification is recognized and trusted globally. This has an impact on the increasing demand of local and foreign companies to implement the MUIS Halal Certification scheme. Meanwhile, Malaysia has the Jabatan Kemajuan Islam Malaysia (JAKIM). It should be a concern. Most Islamic countries depend on meat imports from nonMoslem countries (Brazil US \$ 4.1 Billion, Australia US \$ 2.3 Billion, India US \$ 2.1 Billion, US \$ 1.0 Billion, France US \$ 0.7 Billion). This means that these countries require certification on the production of halal foods in order to export to the Moslem countries market. Therefore, the trade of halal certification services is very important and simultaneously the halal certification agency has a dominant role (Mori, 2015).

- Halal Market Overview in Japan

1) Halal Market in Tourism Context

Tourism Context is one of the largest sectors in the Japan's economy. Japan's internal tourism consumption in 2011 is estimated to be 21.5 trillion yen. According to Tourism Sattelite Account, the contribution of tourism sector directly and indirectly toward the Gross Domestic Product in 2011 amounted to 46.5 trillion (5.0\%). A total of 4 million jobs run under the tourism industry, providing $6.2 \%$ of total employment in Japan in 2011. Income from taxes generated by the tourism sector is estimated 4 trillion yen or $5.1 \%$ of the total revenue from taxes in 2011 (Septalia, 2016).

Based on the statistical data collected in the White Paper on Tourism in Japan: The Tourism Situation in FY2013, in comparison with the world's international tourism, Japan is ranked 20th in the world, and ranked seventh in Asia. Japan's revenues from the tourism sector rose to $\$ 14.6$ billion from 5.37 billion dollars in 2011. Meanwhile, in the period of 2013, it rose again to 15.1 billion dollars, year on year Japan's revenue from the tourism sector increased about $3.8 \%$. This is of course directly proportional to the number of foreign visitors to Japan in 2013 recorded up to 10.36 million people (year on year to increase of 24.0\%). This figure exceeded the previous achievement that only reached 8.61 million in 2010, as well as the first time that Japan reached 10 million visitors a year (Septalia, 2016).

As a country that aware of the importance of tourism, Japan has an appeal that attracts the foreign tourists to come to visit Japan. Various reasons for foreign tourists to visit the destination countries, among others: due to the need for shopping, the interest in culture, natural beauty and so forth.

Based on a survey result conducted by JNTO in 2006-2007, the three main motivations of foreign visitors coming to Japan are for shopping (34.8\%), visiting the historical places and enjoying the traditional Japanese culture (32.4\%), spa or relaxation (onsen) $(32.1 \%)$. In addition to the natural beauty (28.5\%), another appealing of the Japanese people's life (27.7\%) and Japanese culinary $(19.4 \%)$ become the motivation of foreign tourists to visit Japan. (Septalia, 2016)

2) Shopping Tour 
Shopping has become the first order of reasons for foreign tourists coming to Japan. According to a survey conducted by JNTO at the eight international airports and Hakata port, one of the comments from the respondents stated that their reason to come to Japan is to have shopping. Yen deprivation becomes one of the factors that resulted goods in Japan are cheaper, which makes foreigners interested in shopping to Japan. Foreigners who come to Japan can buy the luxury goods at affordable prices. Another reason for Japan as a place of shopping is because Japan offers goods whose an exclusive and limited model with secondbrand quality only in Japan (Murayama, 2007).

Shopping places in Japan include Akihabara, Ginza, Roppongi, Shibuya, Shinjuku, Shinsaibashi, and Umeda. Akihabara is located in Chiyoda-ku, Tokyo. Akihabara is a center for electronic goods sales that is very famous for foreign tourists. Akihabara increasingly crowded with the opening of the Tsukuba Express by the government of Japan in 2005.

Besides Akihabara, Ginza that arelocated in Chuo-ku, Tokyo is also one of the famous shopping areas in Japan. Ginza is not only famous in Japan, but also outside of Japan as a top class shopping place. Roppongi is another shopping area located in Tokyo city. Roppongi is located in Minoato-ku, Tokyo.Roppongi is famous for shopping and entertainment district center.

Umeda and Shinsaibashi are other popular shopping spots in Japan located in Osaka. In Shinsaibashi, there are popular shopping centers like Daimaru and fashion stores such as Parco and Crysta Nagahori as well as some famous brands such as Channel and Gucci.Umeda are other shopping spots in Osaka. In Umeda there is the EST fashion house, Urban Terrace Chayamachi, and Yodobashi Camera electronic center. There are also underground shopping malls like Hankyu Sanban Gai, White Umeda, Diamor Osaka and Dojima Underground Center (Septalia, 2016).

3) Spa / relaxation (onsen)

Onsen is a term for a hot spring bath which is one of the attractions of Japan's tourism since long time ago. According to the onsen act (onsen-sho), the onsen is any spring that emanates from the ground as the warm water, water containing minerals, steam or gases with an average temperature of 25 degrees or more. There are 9 types of onsen of which are nisankatanso-sen (springs containing high carbon dioxide), tansansuisoen-sen (springs containing hydrogen carbonate), enkabutsu-sen (springs containing chloride), ryusan-sen (springs containing sulfate), tetsu-sen (springs containing acid), hosano-sen (springs containing radioactive) and tanjun (springs not containing substances present in other types of onsen but having temperatures greater than 24 degrees) (Zulaeha, 2014).

4) Japanese Culinary

Although it is not the first rank in the motivation of foreign tourists to come to Japan, food or culinary remains one of the attractions of Japan tourism, as the typical of Japanese culinary is considered unique for foreign tourists. Japanese food is famous among foreign tourists not only because of its beautiful appearance, but also its cleanliness. Some of the famous Japanese cuisine include sushi, sashimi, okonomiyaki, soba, ramen, gyoza, yakiniku and so on (Zulaeha, 2014).

5) Historical Sites

Historical sites are one of the attractions of Japanese tourism, both for local and international tourists. Japan seeks to register its historical sites as the world cultural heritage. According to statistics contained in the 2011 Statistical Handbook of Japan, there are sixteen world heritage sites (twelve cultural heritages and four natural heritages) listed in the UNESCO, among others the historical village of Shirakawa-go and Gokayama in Gifu, Toyama: Nikko templein Tochigi, Buddhist monument in the Horyu-ji area of Nara, 
Hiroshima Peace Memorial (Genbaku Dome) in Hiroshima, Yakushima island in Kagoshima, and Himejo-jo temple in Hyogo.

In June 2013, the world cultural heritage sites of Japan increased by one, namely Mount Fuji located in Shizuoka and Yamanashi. Mount Fuji is officially listed as one of the world heritages in the World Heritage Committee in Cambodia on June 16 to 27, 2013.In addition to actively in registering the intangible cultural heritage to UNESCO, since 2008, there have been twenty Intangible Cultural Heritages $(\mathrm{ICH})$ registered in UNESCO. The ICH registration in Japan was initially commenced by the Asia Pacific Cultural Center for UNESCO (ACCU) and the Agency for Cultural Affairs (Bunkacho) (Zulaeha, 2014).

Traditional Culture

Another point of interest for foreign tourists to come to Japan is to experience or see firsthand the famous traditional Japanese culture of Kyoto Gion Matsuri. This Kyoto Gion Matsuri is an annual festival held every July.The Gion Matsuri is one of Japan's Intangible Cultural Heritages registered in UNESCO.

In addition to the Gion Matsuri in Kyoto, there are many other traditional Japanese cultures among others; Kabuki Theater, a traditional Japanese theater that has existed since the Edo period. Kabuki is only played by men despite of the female role,the Ningyo Johruri Bunraku, a puppet theater show containing a blend of narrative story and instrumental music, the Hitachi Furyomono, a parade held during the cherry blossom festival every April in Hitachi city,the Sekishu-banshi, a paper-making technique in the Iwami region, Shimane Prefecture, and also the Dainichido Bungaku,the ritual dance and imperial palace music (Zulaeha, 2014).

\section{THEORY}

\subsection{A State Centered Approach}

A state-centered approach has the ultimate goal of understanding the politics and dynamics of competition. This means that the national policy makers are not bound by the interest group's agenda but to act for the greater good of the state. This approach shows that the purpose of government intervention is to promote a certain industry that may not have the means to succeed (Oatley, 2016).

\subsection{Analysis of Japan'sHalal Market with A State Centered Approach}

\subsubsection{Tourism Act in Japan}

In order to advance its tourism, Japan has several programs established and continue to be developed. In addition to tourism institutions or organizations run by both government and private parties, the government of Japan also proclaimed act relating to tourism. The legislation on tourism has become one of the policy strategies on tourism development in Japan. The act made by the government becomes a reference or foundation in the implementation of a program. There are two acts related to tourism, which are the Kankou Rikkoku Sokushin Kihon Hou and the Keikan Midori Sanpo. 


\subsubsection{Tourism Promotion Act of Kankou Rikkoku Sokushin Kihon Hou}

Kankou Rikkoku Sokushin Kihon Hou means this Act positioned tourism as one of the pillars of the Japan policy in 21st century. The Tourism Promotion Act stated that those related to the development of tourism are all Japanese citizens namely the central government, local government, communities and the actors of the tourism industry. With the good cooperation of all elements, the development of the tourism program will be running well.

\subsubsection{Keikan Midori Sanpou}

The Keikan Midori Sanpoucomprises of the Three Actsin the Landscape and Reforestation that is a recision of the Act dealing with landscape conservation and urban cultivation, among others the Law on Outdoor Adversiting Materials and the Law on Urban Green Space Protection. The act was formulated in 2004 to reshape the landscape especially in urban areas.

The government of Japan proposes this act to manifest the concept of beautiful nation and nation-based policy of tourism so as to create the beautiful and green sceneries in Japan.

\subsection{Policies Related to Tourism}

\subsubsection{Visit Japan Project}

Japan implements the Visit Japan Project which is a specific step of Visit Japan Promotion launched in 2003. The project was firstly implemented for 14 countries and regions that became the priority market of Japan tourism, namely Australia, UK, Canada, China, France, Germany, Hong Kong, Indonesia, Malaysia, Singapore, South Korea, Taiwan, Thailand and the United States. The existence of an additional budget in 2014 allowed the number of countries that became the priority market of Japan tourism to increase into six countries: India, Italy, Philippines, Russia, Spain, and Vietnam.

Visit Japan Campaign was designed by the Prime Minister Junichiro Koizumi with the aim atachieving the target of 10 million international visitors to Japan in 2010. Japan's tourism attraction is through a soft power approach that can inspire the international public to be interested in visiting Japan. This contributes to the creation of mutual understanding through inter-state exchanges. In an era of increasingly shrinking population, the rise of international visitors to Japan is capable of bringing consequences in regional revitalization and business expansion. For that reason, the public and private sectors work together, coordinated by the Japan Tourism Agency.

\subsubsection{Easing of visa requirements}

The easing of visa requirements is one of the strategies that contribute to encouraging the increase of foreign visitors to Japan. The majority of developed countries have obtained visa exemption for visiting Japan, while for developing countries, this policy is also beginning to be implemented. In April 2004, Hong Kong got a visa-free opportunity. In July 2013, to commemorate 40 years of friendship and cooperation between Japan and ASEAN, Thailand and Malaysia gained the same opportunity. While Indonesia gained expansion of multipleentry visa duration (for 15-30 days). Similarly for other ASEAN countries such as Philippines, 
Vietnam, Cambodia, Laos and Myanmar. In fact, more than half the number of foreign tourists visiting to Japan comes from East Asia and ASEAN countries.

\subsubsection{Low Cost Carrier Policy}

It has also begun to be implemented the improvement of flight network services. The number of international flights to and from Japan experienced a decline in 2009 and 2010 in the period after 2003 due to the impact of Lehman Shock. However, the number of international flights to and from Japan showed steady growth in the following years. The number of flights increased by more than 1.5 times from flights each week in 2003 to 3,447 flights in a week in 2013. In connection with the implementation of Low Cost Carrier on international flights, the number of flights to countries in the East Asia and ASEAN region has grown rapidly since 2010 .

Japan is an archipelagic country whose main route for international visitors is through air transport. As a result, an increase in flight network is considered capable of having a significant impact in triggering an increase in the number of foreign visitors to Japan.

\subsubsection{Tax-Free Policy}

Tax-free policy at stores in Japan has also begun to be implemented. As of October 1, 2014, the tax-free system in Japan was changing. The number of items eligible for tax exemptions is increasing, making shopping activities in Japan more fun and affordable. Tourists in Japan can now buy consumer goods such as medicines, food and cosmetics, from certain stores that are tax-free, with some applicable terms. Japan Tourism Agency seeks to double the number of small shops in different regions, especially those selling local specialties to help promote shopping in the prefectures. Pharmacies, cosmetic shops and sake shops are a number of stores that are looking for licenses to obtain the tax free space.

Based on the rapidly growing of global Moslem population and the prediction that many Moslem tourists will enter Japan, there are many facilities and infrastructures that support the needs of Moslem tourists. Halal tourism, the last few years has become a new strategy in the Japan's world of tourism in relation to attracting Moslem tourists.

\subsection{Halal Tourism Information Service}

In Tourism Working Group Meeting organized by Asia-Pacific Economic Cooperation (APEC) in Cusco, Peru in April 2014, Susumu Kida as representative of Japan Tourism Agency presented Recent Progress in Tourism Policy in Japan: Policies for Economic and Social Return. Whereas in addition to visa clearance policies for ASEAN countries, an increase in the number of Muslim tourists entering Japan (Septalia, 2016).

Beginning in 2013, various information or promotions aimed at generating interest for Muslim visitors worldwide to Japan. Here are some sites or online information for Muslim travelers. 


\subsubsection{Japan Welcome Guide for Muslim Visitors}

Japan Welcome Guide for Muslim Visitors created by Japan National Tourism Organizations (JNTO). Inside the official website, provided a lot of information about the tour is comfortable and fun. Starting from basic information such as weather and seasons in Japan, time difference between Japan and other countries, money exchange, ATM (Automated Teller Machine) location, emergency contact, free internet area, tax-free shop information, and links on local tourism sites such as Kyoto, Kobe, Fukuoka , Osaka, and Shoryudo (Toyama, Ishikawa, Fukui, Nagano, Gifu, Shizuoka, Aichi, Mie and Shiga).

Like most information sites, the JNTO Muslim visitors' special page comes with information about Muslim-friendly hotels and restaurants, as well as mosques or facilities for worship throughout Japan.

\subsubsection{Muslim Friendly Kyoto}

Kyoto is one city with a beautiful natural atmosphere and thick with a touch of traditional culture presents a variety of uniqueness, thus becoming one of the destinations in Japan. Ometenashi towards Muslim visitors became a strategy that Kyoto is now developing. Based on a press release launched by the Kyoto Convention Bureau (KCB) on December 26, 2013.

This site was created with the aim to become an information medium and make it easier for Muslim visitors in Kyoto. The site is under the auspices of the Kyoto Muslim Association (KMA). The information presented is in the form of a Muslim-friendly location in Kyoto, including restaurants certified by KMA. Coordination efforts undertaken by KMA and Kyoto City is one of many steps taken by Japan in advancing the halal market, especially in the field of tourism.

\subsubsection{Hakuba Muslim Friendly Project}

Hakuba Muslim Friendly Project is a consortium of service units located in Hakuba Goryu, Japan. Their first promotion in Malaysia in June 2015 is located at Bangi Shopping Complex, Kuala Lumpur. As one of the most popular mountain areas in Japan, Hakuba is one of Japan's favorite tourist destinations for snow lovers and skiing. Aware of its promising tourism potential, Hakuba offers the Muslim Friendly Project a Muslim-friendly area. On its site there are interesting destinations in Hakuba Goryu area.

\subsubsection{Sendai Information for Muslim and Vegetarian Visitors}

This information page was released by Sendai Tourism Website on February 10, 2015. Similar to other tourism information sites, this site also provides information on restaurants, accommodation and other facilities in Sendai that make it easier for vegetarian Muslim visitors. There is also a list of recommended restaurants and shops in Sendai, complemented by some hints in reading information about categories provided in the restaurant. It contains information on whether to provide halal meat, whether Muslim owners and Muslim chefs, whether to provide alcohol or not, as well as information on facilities for Muslims. This site is under the auspices of The Islamic Cultural Center of Sendai (ICCS). 


\subsubsection{Eat \& Stay: Kansai Muslim Friendly Guide}

The Kansai area is one of the areas in Japan that has launched a Muslim-Friendly App application that can be downloaded easily on mobile phones. This application, Muslims who will visit Japan especially the Kansai region can easily get information or services related to restaurants and halal food, hotels, and other facilities for the needs of Muslim visitors.

\subsection{Economic Impact}

Economic factors are an important point that cannot be avoided or denied in the context of buying and selling activities, whereas in tourism, it is clearly a form of business in which there are supply and demand. In this case, the destination country is a host, while the tourist arriving into the country is a guest. The host offers deals along with the guest's requests or needs. Practically, if this rule is met, the consequences of course there will be many other guests who are interested to visit, which will automatically boost the country's economy. In terms of industry, of course the products sold will be favored by Moslem tourists due to itshalal value. So,as the businesses can innovate their products and increase revenue for sellers.

\subsection{Political Impact}

Based on the arguments presented by Katakura Kunio (2002), there are five important points related to Japan's policy towards Islam. First, Islam is not something represented by a nation or country, it is important to develop relationships and exchanges with nongovernmental organizations. The need for asymmetrical interaction and discussion. Second, dialogue must be developed with different parties from different layers not only state or government agencies but also private institutions, academic and research institutions, media, groups or women's organizations, and volunteer organizations. On the Japan's side, in creating appropriate contacts for such activities, it is more precisely done by non-governmental organizations and public companies such as the Japan Foundation. Third, Japan's strong ties with countries in the Islamic culture has been forged not only through trade but through the development of a nationally developed energy supply system and development project in the long-term. With special attention to ensure that it does not weaken or lower the exchange of relationships that have been established with oil producers from Moslem countries in the Persian Gulf region. Fourth, as part of the internal effort to internationalize itself, Japan should pay a particular attention to Moslem communities and visitors in Japan. This should be implemented for example in the form of construction of public facilities such as at the airport that accommodates the Moslem interest. Fifth, Japan should promote regional studies and expertise in the language of countries relevant to Moslem countries, not only Arabic, but also Persian, Turkish, and other languages in the Eurasian region. Kunio (2002) stresses that the special attention to the five points described above is crucial in developing a positive interaction and dialogue with the Moslem world and the Moslem communities.

Given the increasingly prospective of the world's Moslem market, this could be one of Japan's political or public diplomacy strategies to defend its image in the eyes of Moslems and the Moslem world in general. This may also concern the Japan's interests in its economy. 


\section{CONCLUSION}

There are several factors that affect the development of the halal market which are the growth factor and the rapidly growing of the world's Moslem population, as well as the halal principle itself that can be accepted even in demand by the wider communities which is not limited by Moslems, but also non Moslems. Therefore, a good strategy is required in order to benefit from the development of the halal market. In this case, the government can play a role in making policies that may affect the development of various sectors for example in the economic sector. The state role is very necessary in stimulating its economic development. With the hope of getting a positive response in related institutions and communities, Japan itself has created policies that may be profitable to the economic and diplomatic sides with the tourism-related policy strategies. The role of government of Japanese very active in strategizing toward the interests of growing its economy.

\section{ACKNOWLEDGEMENT}

This research based on grant scheme of PITTA (Publikasi International Terindeks untuk Tugas Akhir) 2018 or also known as Indexed International Publications for Final Projects toward Universitas Indonesia students. Thank you to Dr. Asra Virgianita as my advisor

\section{REFERENCES}

[1]. Anugrah Wibyaninggar, Septalia (2016). Strategi Pariwisata Jepang dalam Konteks Halal Tourism. Thesis. Kajian Wilayah Jepang, Universitas Indonesia

[2]. Battour, Mohamed (2010). Toward a Halal Tourism Market. Tourism Analysis, Vol.15

[3]. Departemen Perdagangan Republik Indonesia (2015). Hidup Sehat dengan Produk Halal. Warta Ekspor, Vol. 56

[4]. Mori, Takayuki. The Present Condition and the Subject of Halal In Japan, in Comparison with Malaysia. Kobe : Faculty of Commerce, University of Marketing and Distribution Sciences.

[5]. Oatley, Thomas (2016). International Political Economy. New york : Routledge

[6]. Thompson Reuters (2016). State of The Global Islamic Ekonomy 2014-2015 Report. Dubai : DinarStandar

[7]. Sean Ong, 2014. Abenomics 1 Year On Opportunities in Tourism.Tokyo: Kabushiki

[8]. Mori, Takayuki. The Present Condition and the Subject of Halal In Japan, in Comparison with Malaysia. Kobe : Faculty of Commerce, University of Marketing and Distribution Sciences.

[9]. Zulaeha, Elli Rahmawati (2014). Strategi Pengembangan Pariwisata di Jepang untuk Pencapaian 10 Juta Wisatawan Asing Periode 2003-2012. Thesis. Kajian Wilayah Jepang

[10]. Murayama, Keita. Flash Report of the Survey of Overseas Visitors to Japan 2006-2007 by JNTO. Accested June 2018. http:www.tourism.jp?en/column-opinion/highesttravel-motive-to-japan.html. 